\title{
Roads and Routes in Northwestern and Adjoining Parts of Central Asia Minor: From the Romans to Byzantium, with Some Remarks on their Fate during the Ottoman Period up to the $17^{\text {th }}$ Century
}

\author{
Klaus BELKE*
}

The Roman Roads in Asia Minor in general are well-known. This holds true for the overall network of long-distance roads as well as for the technical aspects of their construction and appearance ${ }^{1}$. The increase in our knowledge on the Roman roads of Anatolia during the last decades in many respects owes much to the work of the late David French, who tirelessly followed their traces, recorded techniques and measurements, collected milestones and road inscriptions ${ }^{2}$, and put forward a set of definitions for the various types of roads as well as a useful, if schematic, theoretical approach to their development from the pre-Roman to the post-Byzantine period ${ }^{3}$. He has now published the milestones of the different regions of Asia Minor in seven online volumes.

For the purpose of this paper, I have chosen five aspects of the development of roads from Antiquity to the Ottoman period (until about the $17^{\text {th }}$ century), namely:

- Change in design and appearance of roads

- Change of some main routes

- Maintenance of roads

- The arrival of the Seljuk Turks in Asia Minor and its impact on the road system in areas remaining under Byzantine rule

- Continuity and change of routes and roads in the Ottoman period up to the $17^{\text {th }}$ century

\section{Change in design and appearance of roads}

The long-distance roads of Anatolia, as well as many regional and secondary roads, were, as in most parts of the Roman Empire, generally designed for vehicular traffic. Not only numerous sources, but also ruts in preserved stretches of the roads testify to this fact. The importance of vehicular traffic in Asia Minor's provincial areas as early as the $1^{\text {st }}$ century $\mathrm{AD}$ is highlighted by

\footnotetext{
* Dr. Klaus Belke, Österreichische Akademie der Wissenschaften, Institut für Mittelalterforschung, Abteilung Byzanzforschung, Hollandstraße 11-13, A-1020 Wien, Österreich (Klaus.Belke@assoc.oeaw.ac. at; https://orcid.org/0000-0002-6189-7523).

${ }^{1}$ See Schneider 1982 (general introduction to problems, methods, and results); Chevallier 1998 (detailed description of various aspects, mainly on Italy and Gaul); Pekáry 1968 (especially on juridical and administrative questions); for building techniques in Anatolia see French 1980, 704; French 1981, 19-22; for different building techniques see Schneider 1982, 31-35; good overview also in Adak 2019.

${ }^{2}$ French's scattered preliminary publications are listed in http://biaa.ac.uk/research/item/name/surveyof-roman-roads-and-milestones (last access 18.5.2020).

${ }^{3}$ French 1974, 144; French 1980, 699-705; French 1993, 448-452.

${ }^{4}$ See http://biaa.ac.uk/publications/item/name/electronic-monographs (last access 18.5.2020).
} 
inscriptions and archaeological observations ${ }^{5}$. There were, however, exceptions to this rule, notably in mountainous regions such as Lycia and parts of Pisidia ${ }^{6}$. Outside the mountain areas, main roads for vehicular traffic were wide enough (usually more than six meters) for two wagons to pass easily, and in Anatolia they were mostly paved by the end of the Roman imperial period. French has given three different definitions for highways (designed for vehicular traffic) and roadways (designed for non-vehicular traffic): highway more than and roadway less than $2.5 \mathrm{~m} \mathrm{wide}^{7}$; more/less than $3.25 \mathrm{~m}^{8} ; 6.50 \mathrm{~m}$ (highway), $3.25 \mathrm{~m}$ (roadway) ${ }^{9}$.

Roman roads were built mainly on behalf of the State, for rapid military movement, to serve administrative purposes and for the so-called cursus publicus, an institution run by the state that provided means of transport along certain main roads for a limited circle of imperial couriers, high-ranking military leaders, civil servants, and official delegations as well as, perhaps only from the fourth to the sixth century, for certain transports of goods for the army or the imperial court ${ }^{10}$. These roads were not primarily built for merchants or private travellers, although these too had the right to use them freely ${ }^{11}$. The state was responsible for maintaining and organizing the public roads, but in most of the cases, especially in the provinces, the possessors (proprietors of land along the roads) and, sometimes, the communities had to pay the maintenance costs ${ }^{12}$. We know from milestones and road inscriptions that in spite of these efforts, already in the Roman imperial period, roads often collapsed or were in bad condition because of their age and therefore had to be repaired ${ }^{13}$. Nevertheless, in the $4^{\text {th }}$ century, it was not only possible but quite usual to travel across Asia Minor in carriages. For instance Julian, who had invited the philosopher Eustathios to Constantinople, offered him a permit to use a carriage of the cursus publicus with two additional pack horses; it seems, however, that Eustathios did not make use of the emperor's permit for travelling to the capital; for his return, the permit arrived too late, a fact which the philosopher appreciated very much; he calmly returned to Cappadocia on foot ${ }^{14}$. Well-known is the fate of Kimon, son of the rhetor Libanios, who fell from his apene e (a sort of wagon) on his way from Constantinople to Antioch, an accident from which he later died ${ }^{15}$. Gregory of Nyssa travelled to Jerusalem on a

\footnotetext{
${ }^{5}$ See e.g. the inscription published by Mitchell 1976; for ruts in a Roman road see fig. 1.

${ }^{6}$ French 1981, 21.

${ }^{7}$ French 1974, 144.

${ }^{8}$ French 1980, 703.

${ }^{9}$ French 1993, 446.

${ }^{10}$ Kolb 2000, 49-226; for transport of goods 66-70, 96-98.

${ }^{11}$ Pekáry 1968, 1-7 (mainly after Digesta 43, 8, $2 \$ 21$-22 [Corpus Iuris Civilis I, recognovit P. Krueger -
} Th. Mommson, editio stereotypa sexta, Berlin 1893, 684]).

${ }^{12}$ Pekáry 1968, 93-171, passim; Rathmann 2003, 136-142.

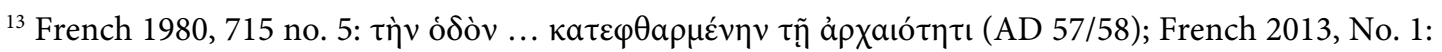
vias a novo munierunt (AD 78); French 2013, No. 64: viam vetustate corruptam restituit (AD 115/16); French 2012, No. 166: Viam Tauri vetustate conlapsam ... cum pontibus institutis restituit (AD 216/17); French 2012, No. 165: [viam] Tauri montis fr[equentissi]mis inluvionibus [dirutam ac cae]sis rupibus ac dilat[atis itineri]bus cum pontibus [institutis rest]itutam perfece[runt] (AD 217/18).

\footnotetext{
${ }^{14}$ Julien, Lettres 34-36 (Bidez 62-64 and 37-38).

${ }^{15}$ Libanios, Autobiography, 279-280.
} 
carriage of the cursus publicus in an official mission ${ }^{16}$. John Chrysostomus when summoned from Antioch to become bishop of Constantinople, travelled all the way through Asia Minor on a redion or raeda of the cursus publicus (that is an open, light, four-wheeled carriage) ${ }^{17}$.

In Late Antiquity or the early Byzantine period (roughly until 650), there are more observations and complaints about bad road conditions in various genres of sources. In 362 the emperor Julian used a carriage (vehiculum) ${ }^{18}$ to travel mostly along the so-called Pilgrim's road from Constantinople to Antioch. Julian also described a stretch of the road from Antioch to Beroia/Halab, which went partly on boggy, partly on mountainous ground. Everywhere it was very rough, there were stones lying in the bog as if placed intentionally, but without any proper technique. By contrasting this example with the better, Julian implies that in general road conditions and construction techniques were better in other cities ${ }^{19}$. Procopius' panegyric On Buildings is especially precious for its information on roads in the age of Justinian ${ }^{20}$. Procopius mentions roads or bridges whose condition constituted a real or even mortal danger for travellers. Justinian and Theodora paved a stretch of a road from Bithynia to Phrygia, which constituted a mortal danger to men and animals after heavy rainfalls and snow thaw because of the boggy ground ${ }^{21}$. Other sections were narrowed or washed away by erosion. Rivers had to be forded in the absence of bridges. To improve the situation for the passengers the emperor rebuilt and paved these stretches, widening the road, making new bridges and sometimes cutting the rock away. An entirely new road over the mountains with only two new bridges over the Drakōn/Yalakdere river in Bithynia replaced more than twenty dangerous crossings of the old road in the valley ${ }^{22}$. The emperor's efforts also included a new bridge over the Pharnutis/Karadere river west of Nikaia ${ }^{23}$, and above all the famous bridge over the Sangarios/Sakarya river ${ }^{24}$, in place of a dangerous pontoon, which Theophanēs described as a wooden bridge ${ }^{25}$. A bridge over the Siberis/Kirmir river near Sykeōn replaced a ford, where many people perished in sudden floods ${ }^{26}$. Procopius noted that Justinian made the roads near Règion west of Constantinople passable for wagons ${ }^{27}$, as well as those between Helenopolis/Hersek and Nikaia/İznik ${ }^{28}$, and in the vicinity of Antioch ${ }^{29}$. His emphasis in these passages suggests that this had already become unusual. Given the immense network of Roman roads in and

\footnotetext{
${ }^{16}$ Gregorii Nysseni Epistulae 2, 12 (Pasquali 17).

${ }^{17}$ Palladios, Dialogue 5 (ed. A.-M. Malingrey - P. Leclerc I, 114).

${ }^{18}$ Ammianus Marcellinus 22, 9, 13.

${ }^{19}$ Julien, Lettres 398 (Bidez 180); French 1993, 454.

${ }^{20}$ French 1993, 450, 452-454; Belke 2000, 118-122; Belke 2020, 265-266, 981, 1047.

${ }^{21}$ Prokopios, De aed. V 3, 12-15.

${ }^{22}$ Prokopios, De aed. V 2, 12-14.

${ }^{23}$ Prokopios, De aed. V 3, 4-6.

${ }^{24}$ Prokopios, De aed. V 3, 8-11.

25 Theophanēs 234 (a. m. 6052).

${ }^{26}$ Prokopios, De aed. V 4, 1-4.

${ }^{27}$ Prokopios, De aed. IV 8, 4-9.

${ }^{28}$ Prokopios, De aed. V 2, 12-14.

${ }^{29}$ Prokopios, De aed. V 5, 1-3.
} 
around Anatolia, Justinian's efforts were limited and the repaired stretches were no longer than 15-20 kilometres. So overall it still appears that the road network had deteriorated ${ }^{30}$.

Archaeologically, things look a bit different. Several roads, usually laid on or beside earlier road surfaces, have reasonably been dated to the $5^{\text {th }}$ or $6^{\text {th }}$ century. They share some common features. Surface stones tended to be larger, and the surface itself smoother than in the Roman period. The roads, however, were narrower, averaging only about $3.5 \mathrm{~m}$; steps were added, to steep stretches of these "roadways", which facilitated the sure footing of pack animals, but impeded vehicular traffic ${ }^{31}$. To French's three examples, add the descent called Kirkmerdiven ('Forty Steps') towards the lake on the Helenopolis-Nikaia road, which was stepped and less than $3 \mathrm{~m}$. wide. It was later than Justinian's wagon road and not designed for vehicular traffic ${ }^{32}$. The difference can be seen in the Döşeme Boğazı in Pamphylia (one of French's examples), where the broad, rough surface of the Roman Via Sebaste with its ruts from vehicular traffic (fig. 1) is contrasted with the narrower but smoother surface of the Byzantine (here in Cilicia: fig. 2) and/or (here more probably) Ottoman fabric (fig. 3). These narrower, smoother Byzantine roads were repeatedly repaired more or less in this style during the later Byzantine and Ottoman periods.

Many roads were obviously neglected in Late Antiquity, and if rebuilt, not really suited for vehicular traffic, although rustic two-wheeled oxcarts could jolt over these stepped roads too. These simple oxcarts, usually equipped with disc wheels, survived in rural Anatolia nearly unchanged until the very recent past. The Byzantines seem to have developed a more effective way to fix the axle to the composite disc-wheel, an innovation which the Turks did not adopt ${ }^{33}$. The use of wagons and carts decreased gradually in favour of pack animals. In the $6^{\text {th }}$ century wagon traffic was practically confined to two-wheeled oxcarts used for short-distance transport of raw materials and goods from the producers to the next market place or harbour, and to military baggage trains. Did wagons fall out of common use because the roads were not fit for them anymore, or could roads become narrow and stepped because wagons had practically disappeared? Richard Bulliet has concluded that in the Near East the phenomena were mutually interrelated ${ }^{34}$, but his conclusions cannot be extrapolated directly to Anatolia, because wagons were here replaced by pack donkeys, mules and, to some extent, horses, not, by the more competitive camels. According to Diocletian's price edict, a camel could carry half the weight of an oxcart's load ${ }^{35}$. A medieval mule or packhorse could carry ca. $85 \mathrm{~kg}$, a donkey less than $60 \mathrm{~kg}$, including ca. 16-19 kg for the pack saddle $^{36}$. Higher estimates have also been made for these loads. Vehicular traffic of course had been known in Anatolia from earlier periods, but the intensive use of different types of carts, wagons, and carriages was introduced to Asia Minor by the Romans, and began to disappear when

\footnotetext{
${ }^{30}$ Loungēs 1994-1995, 37-42; Haldon 2006a,136-38; Haldon 2012, 118-120.

${ }^{31}$ French 1993, 446-448.

${ }^{32}$ For a modern description see Lefort 1995, 214.

${ }^{33}$ Bryer 2002, 112.

${ }^{34}$ Bulliet 1975, 16-27.

${ }^{35}$ Cf. Bulliet 1975, 20-22: ca. 400 and 200 kg.

${ }^{36}$ Haldon 2006a,146.
} 
the Roman-Italian cultural influence and technological skills gradually faded away ${ }^{37}$. A combination of the decreasing need for vehicle roads, the reduced economic resources of the state, and cultural change would have led to road construction on a smaller scale and their increasing neglect.

\section{Change of some main routes in Asia Minor ${ }^{38}$}

After the Arab incursions into Asia Minor began in mid-seventh century, the military, political and economic situation of the eastern parts of the Byzantine empire changed drastically, as east and south-east Anatolia fell temporarily to the invaders. Insecurity prevailed in the rest of Asia Minor $^{39}$. Many long-distance roads from Constantinople to the east were simply cut off at the borders (roughly along the ranges of the Taurus and Antitaurus mountains) or were used only for diplomatic exchanges and a minimal trade in commodities. Inside Anatolia the main lines of communication were maintained, but traffic on some traditional roads faded in favour of others. While the so-called Pilgrim's Road from Chalkēdōn via Nikaia and Ankyra/Ankara to Cilicia and Syria had been the main traffic artery across Anatolia until the $7^{\text {th }}$ century, new economic and military centres arose, such as Amorion/Hisar, an important node already in the early Byzantine period, which became the seat of the strateggos of the Anatolikon theme ${ }^{40}$, and Dorylaion/Şarhüyük near Eskişehir, an aplekkton (a camp and meeting point of the Byzantine armies) ${ }^{41}$. From the $8^{\text {th }}$ century onwards, several roads led via Dorylaion, Amorion and Ikonion/Konya to the Cilician Gates (fig. 4). Ankyra remained a first-order fortress and retained its nodal importance, especially for routes to the east; this fact is attested by an Armenian itinerary (Młonač ap ' $k$ ), for which dates between 638 and 762 have been proposed. It shows a route (obviously a main route for the Armenians) from Dvin via Theodosiupolis/Erzurum, Kolōneia/Şebinkarahisar, Neokaisareia/Niksar, Amaseia/Amasya, Gangra/Çankırı, and Ankyra/Ankara to Constantinople and further to Rome ${ }^{42}$. Two $10^{\text {th }}$ century Arabic itineraries too indicate roads from the east to Constantinople via Ankara $^{43}$. But the more westerly city-fortresses now became the main hubs of diagonal connection through Asia Minor. However, all these "new" roads existed already in the Roman period, as can be seen from the Peutinger Table, milestones and extant road surfaces, although they did not yet form the main artery to Cilicia and Syria. A road from Nikaia to Dorylaion is found in the Peutinger Table, but the exact routing is debated; a more or less direct line via Armenokastron/Ermeni Pazarı seems more likely than a route through the Sangarios valley ${ }^{44}$. The road through the valleys of the Sangarios and the Karasu, its tributary, existed from antiquity but became especially important in the middle ages ${ }^{45}$. Likewise, there were several roads between Dorylaion and Amo-

\footnotetext{
${ }^{37}$ Bulliet 1975, 26.

${ }^{38}$ For some issues treated here briefly see now more detailed Kaya 2019.

${ }^{39}$ Lilie 1976, passim.

${ }^{40}$ Belke - Mersich 1990, 143.

${ }^{41}$ Kōnstantinos Porphyrogennētos, Three Treatises, 80-81, 155-157; Huxley 1975; Avramea 2002, 57-58.

${ }^{42}$ See The Geography of Ananias of Širak in Hewsen 1992, 320-321 (Appendix VI).

${ }^{43}$ Ibn Hauqal I 190-191, and al-Muqaddasī (quoted by Honigmann 1936, 262, 270-271).

${ }^{44}$ Belke 2017, 61-65; Belke 2020, 273; see below pp. 87-88.

${ }^{45}$ Belke 2017, 57-61; Belke 2020, 270-273.
} 
rion and between Amorion, Laodikeia Katakekaumenē/Lâdik and Ikonion, one of which is incorrectly represented on the Peutinger table; others are attested epigraphically or archaeologically by remains of road surfaces and/or bridges ${ }^{46}$. Even more westerly routes were preferred from the $10^{\text {th }}$ century, especially after the sack and destruction of Amorion in $838^{47}$. These routes went to Ikonion via Kotyaeion/Kütahya, Akroinos/Afyon Karahisar and Philomēlion/Akşehir. Most stretches of these roads were known from antiquity, but some variants may have first developed in the middle Byzantine period ${ }^{48}$. So, an "intermediate road" is attested only in the early Komnenian period. It led from Dorylaion via Nakoleia/Seyyit Gazi, Santabaris/Bardakçı to Hebraiikè/probably Hanköy, where it separated from the road to Amorion, and went on via Kedrea (near Bayat) and Polybotos (near Bolvadin) directly to Philomēlion. In the Ottoman period, it served as main road for the army and pilgrims alike ${ }^{49}$. Generalizing from these observations, it can be said that the Byzantines created and built very only few entirely new roads. But in some instances their main lines of communication were different from those chosen by the Romans.

\section{Maintenance of roads}

How usable were Anatolia's roads in the middle Byzantine period? Although there is very little direct evidence in the sources, the state had to organize at least a minimum of maintenance and repair of roads and bridges in order to facilitate rapid army movements, the work of administration and tax collectors, but also to expedite trade, which grew in importance between the end of the Arab incursions and the coming of the Turks ${ }^{50}$. The traditional terms demosia hodos and basilike hodos, mentioned in historical sources, as well as in tactical treatises and in documents, suggest that road maintenance was still the responsibility of the imperial treasury ${ }^{51}$. It was usually achieved by labour demanded from those who were living or had property along these roads ${ }^{52}$. How successful were these efforts? Although there were very few specific complaints about bad road conditions during campaigns, roads were sometimes characterized as narrow or difficult. Remarks like this may sometimes be regarded as a literary topos, but are in accordance with French's observations on the narrowness of Byzantine roads ${ }^{53}$. In 877 the emperor Basilius I had to burn the shrubs and cut down the trees growing on a road near Kukusos/Göksun in Cappadocia, before he could pass with his army ${ }^{54}$. The armies of the First Crusade, which in 1097 went to Nikaia via Nikomèdeia/İzmit, first had to clear the road between the two cities with swords and axes, admittedly in a state of insecurity caused by the presence of the Turks ${ }^{55}$. In this instance, one

\footnotetext{
${ }^{46}$ Belke 1984, 97-99; Belke - Mersich 1990, 143-46.

${ }^{47}$ Taeschner 1924, 93.

${ }^{48}$ Belke - Mersich 1990, 144-145; Kaplan 2000, 88-89.

${ }^{49}$ Anna XI 3, 5; XV 3, 6; 4, 1-3; the northern part of this road (still from Amorion) is already attested by an Arabic itinerary of the $9^{\text {th }}$ century (Ibn Hurdādbih 101 [translation 74]); Belke - Mersich 1990, 143-145; see also below p. 88 .

${ }^{50}$ See the overview in Laiou - Morrisson 2007, 90-165.

${ }^{51}$ Dagron - Mihăescu 1986, 219.

${ }^{52}$ Stauridou-Zaphraka 1982, 32-38, 40-44; Haldon 2006a, 137-138; Avramea 2002, 59-61.

${ }^{53}$ E.g. Theophanēs 312 (a. m. 6116), on Hērakleios' march to the east in 626.

${ }^{54}$ Kōnstantinos Porphyrogennētos, Vita Basilii 168; Hild 1977, 134.

${ }^{55}$ Gesta Francorum 176-167; Hagenmeyer 1898, 282-283.
} 
has to bear in mind that the Byzantine government had simply not been able to keep roads in order for quite a long time because of the civil wars and the ensuing Turkish occupation after the battle of Mantzikert in 1071. The same holds true for the reports on bad road conditions during the Second and Third crusades ${ }^{56}$.

Byzantine armies obviously were not normally impeded by bad roads from moving in Anatolia, as two well-known examples show. The army which Rommanos IV led to the battle of Mantzikert/Malazgirt in 1071 travelled ca. $1500 \mathrm{~km}$ across Asia Minor without hindrance (fig. 5). The emperor's baggage train included ochēmata (probably horse- or mule-drawn wagons), which required better roads than oxcarts (hamaxai), but which were burnt in a fire while the army was camping in a plain in the Anatolikon theme. It then crossed the Sangarius river at the well-known Zompou bridge and the Halys/Kizılırmak probably at the "northern" Kesik Köprü (ca. $40 \mathrm{~km}$ south of Kırıkkale) $)^{57}$. Beyond Sebastia/Sivas Attaleiates speaks of two atrapoi (pathways) which headed to the thema of Koloneia/Şebinkarahisar, but the term only seems to be a literary variation for the hodoi mentioned in the next paragraph. Before Mantzikert Rōmanos placed his heavy siege machines on no less than 1000 oxcarts (meaning probably just a very great number). He probably had them transported over a distance of nearly $200 \mathrm{~km}$ from Theodosiopolis/Erzurum, where he had provisioned the army for the last time ${ }^{58}$.

In 1176, the emperor Manuel I wanted to regain the capital of the Seljuks, Ikonion, and thus to destroy the dangerous rival empire. He was accompanied by an especially large baggage train, which consisted not only of pack animals, but also of numerous oxcarts with the heavy siege engines. He assembled his troops as usual in the Ryndakos/Koca Dere valley (i. e. the plains around Lopadion/Ulubat) and travelled "through Phrygia" to Laodikeia (near Denizli). He must have used the well-known Roman road which led via Adrianu Thērai/Balıkesir, Thyateira/Akhisar, Sardeis/Sart, Philadelpheia/Akşehir, and Tripolis on the Meander (near today's Yenicekent) to Laodikeia. The oxcarts which may have first joined the army near Laodikeia were driven slowly, but safely from the valley of the Meander/Menderes River to the narrow mountain pass of Tzybritzē, but here, according to Chōniatēs, they were the main reason for Manuēl's defeat ${ }^{59}$. The accounts of these two campaigns demonstrate that at least certain roads in Anatolia were good enough to carry heavy carts not only on plain terrain, but also in mountainous areas.

As stated above, there was a revival of trading activities in the comparatively peaceful period of the $10^{\text {th }}$ and $11^{\text {th }}$ centuries. Overland connections existed with the Hamdanids of Aleppo via the modified route of the Pilgrim's road ${ }^{60}$, with Trebizond as one of the terminal points of the Silk

\footnotetext{
${ }^{56}$ Odo of Deuil 102-106; Historia de expeditione Friderici 72.

${ }^{57}$ Hild 1977, 81-82; Hild - Restle 1981, 103.

${ }^{58}$ Michaēl Attaleiatēs 107-113 and Nikephoros Bryennios 103-107. See Haldon 2006b, 8-18; Belke 2010, 54-55.

${ }^{59}$ Iōannēs Kinnamos 299-300 (the work breaks off with the report of the march to Tzybritzē); Niketas Choniates 178-182; Belke - Mersich 1990, 118-119.

${ }^{60}$ Dölger - Müller 2003, No. 728a; Dimitroukas 1997, I 155 (caravans carrying merchandise from Constantinople to Aleppo mentioned in a peace treaty of 969); Iōannēs Skylitzēs 321; Belke - Mersich 1990, 353-54 (tribute to be delivered by the Hamdanids to the emperor).
} 
Road $^{61}$, with the Persian countries via Theodosiupolis/Erzurum, and with Attaleia/Antalya, which was, like Trebizond, another land and sea transport intersection ${ }^{62}$. Some of the roads to the east and to Attaleia were even equipped with Imperial road stations, direct successors of the mansiones of Late Antiquity ${ }^{63}$. One may conclude that the conditions of some roads had improved considerably in the $10^{\text {th }}$ and $11^{\text {th }}$ centuries.

\section{The arrival of the Seljuk Turks and its impact on the road system}

Turkish troops, tribes, and plundering groups penetrated Asia Minor as a consequence of the Byzantine defeat at Mantzikert in 1071 and the ensuing decade of civil wars and rebellions. The first Turkish state was created in Byzantine territory around 1080, centered at Nikaia, where Süleymān b. Kutlumuş laid the foundations of the Sultanate of the Rum-Seljuks ${ }^{64}$, followed by Smyrna/İzmir, where the emir Çaka conquered a territory that also comprised some of the Greek islands ${ }^{65}$, and Neokaisareia/Niksar and other cities of north-eastern Asia Minor, where the emir Dānişmend established his own dominion ${ }^{66}$. Land communications were interrupted more radically than during the Byzantine-Arab wars. Until they gradually won back the coastal parts of Asia Minor up to the borders of the Central Anatolian Plateau, the Byzantines had lost control of most roads in Anatolia. Already during the civil wars the omnipresent Turkish groups made it extremely difficult and precarious to cross the country. Insecurity was already widespread two years after Mantzikert. In 1073, Isaak Komnēnos, the brother of the emperor Alexios I, was taken prisoner by the Turks after the desertion of Roussel of Bailleul had caused the defeat of the Byzantines in Cappadocia, and brought to the area of Ankyra, where he was ransomed for a considerable sum. He and his brother Alexios, who had come to rescue him, were attacked at the village of Dektē west of the Sangarios on the march back to Constantinople by a group of Turks ${ }^{67}$. Two or three years later, the situation had deteriorated further. Alexios succeeded in capturing the Frankish rebel Roussel of Bailleul in Amaseia/Amasya and brought him to Constantinople. Alexios was almost killed by a group of Turks en route, while visiting the deserted house of his ancestors around Kastamōn/Kastamonu ${ }^{68}$. After another encounter with plundering Turks at Pontic Hērakleia/Karadeniz Ereğlisi, he received a letter from the emperor ordering him to return to the capital by ship, because the overland routes were said to be blocked by the Turks ${ }^{69}$. All these incidents show that travelling through Anatolia was possible only under strong military protection, if at all. Even this limited use of the Byzantine overland routes was no longer possible one or two years later.

\footnotetext{
${ }^{61}$ Dimitroukas 1997, I 156; cf. Lopez 1945, 29-30, quoting Arabic sources.

${ }^{62}$ Ibn Ḥauqal I 192-93; II 337; Dimitroukas 1997, I 157-158.

${ }^{63}$ Dimitroukas 1997, II 586-597.

${ }^{64}$ Leiser 1998, 860; Belke 2011, 66-67.

${ }^{65}$ Brand 1991, 2134.

${ }^{66}$ Mélikoff 1965, 112-114.

${ }^{67}$ Nikēphoros Bryennios 147-167; see Vryonis 1971, 110-111.

${ }^{68}$ Anna I 3, 3-4; Nikēphoros Bryennios 195-197.

${ }^{69}$ Nikēphoros Bryennios 199-201; see Vryonis 1971, 111-112.
} 
Security along the roads within the areas reconquered by Alexios I and his successors was reestablished only slowly and for a limited period under the so-called Empire of Nicaea. Meanwhile the Rum-Seljuk Sultanate, with Konya/Ikonion as its capital, developed its own lines of communication, which to a great extent followed the routes established by the Romans and the Byzantines $^{70}$. This period of relative security ended with the increasing neglect of the eastern provinces under the Palaeologan emperors and the rise of new Turkish principalities, among them that of the Ottomans, who within a few decades had conquered much of what had remained of Byzantine Anatolia. The main lines of communication, at least in the areas under Byzantine control, had still hardly changed, as a comparison with the Ottoman sources shows, but by-ways and tracks had often to be used in order to avoid clashes with the Turks. Around 1304, the traditional roads from the ports on the southern shore of the Gulf of Nikomēdeia were completely blocked by the Turks, and Nikaia could only be reached by night from the port of Kios/Gemlik on a pathway to the lake and then by boat to the city ${ }^{71}$. The maintenance of roads and bridges was of course impossible during this period. Safe travelling on Anatolia's roads only became possible again after the Ottomans had consolidated their rule over the country.

\section{Continuity and change of some routes and roads in the Ottoman period (up to the $17^{\text {th }}$ century)}

The Ottomans seem to have built some new roads or road sections and created connections which, as far as we know, did not exist before ${ }^{72}$. The diagonal roads across Asia Minor, successors to the so-called Pilgrim's road of Late Antiquity, retained their importance for the Ottoman State. Documents from the beginning of the $16^{\text {th }}$ century attest the Ottoman "Military Road", used by the Sultan's armies. Trading and pilgrim caravans, whose itineraries were documented only a century later, partly followed different routes ${ }^{73}$. The Ottoman military road from Üsküdar/Skutarion to İznik/Nikaia roughly corresponds to the Roman and Byzantine road ${ }^{74}$. As a consequence, between İzmit/Nikomēdeia and İznik the extant old road surface has a mixture of Roman and Ottoman fabric ${ }^{75}$, just as in the Döşeme Boğazı. The caravans always preferred the ferry over the Gulf of Nikomēdia from Dil to Hersek/Helenopolis ${ }^{76}$.

Beyond İznik there were greater divergences from the Byzantine road system as well as alterations within the Ottoman period (fig. 6). Dorylaion had already replaced Ankyra in the middle Byzantine period as main road junction in central Asia Minor. While the Byzantines usually seem to have marched from Nikaia through the valleys of the Sangarios and the Karasu, the Ottoman armies headed south from İznik to Yenişehir, an early foundation (ca. 1300) of Osman himself at

${ }^{70}$ See, e. g., Yavuzcan 2011; Turchetto in print; Redford in print.

${ }^{71}$ Geōrgios Pachymerēs XI 21 (IV 455 Failler).

${ }^{72}$ See the classic work of Taeschner 1924-1926.

${ }^{73}$ See Taeschner 1924-1926, 78-85.

${ }^{74}$ Taeschner 1924-1926, 105-110, 112-116 with tab. 1, 2, 4; the material with indication of sources can also be found (but scattered by dividing the routes into short stretches) in Luther 1989, so for Üsküdarİzmit-İznik 105-106 (Üsküdar-Diliskelesi), 37 (Diliskelesi-Hereke), 51 (Hereke-İzmit), 60 (İznik-İzmit).

${ }^{75}$ Lefort 1995, 216-217.

${ }^{76}$ Taeschner 1924-1926,110-112 with tab. 3 Luther 1989, 37 (Dil-Hersek), 52 (Hersek-K1zderbendi), 70 (Kızderbendi-İznik). 
a location, where no Roman or Byzantine settlement seems to have existed. From there, they proceeded to Akbıyık and by Ermeni Pazarı/Pazarcık/Armenokastron, Bozüyük and İnönü either to Eskişehir or to Kütahya/Kotyaeion ${ }^{77}$. These were variants of the diagonal road known from Byzantine sources.

So the Ottoman military road between İznik and Ermeni Pazarı is probably a new Ottoman road, whose course was determined by the foundation of Yenişehir. The Peutinger Table shows a Roman road from Nicea to Dorileo by an intermediate station called Agrillo ${ }^{78}$. Sencer Şahin proposed hypothetically to equate Agrillo with an ancient settlement southwest of Gökçesu ${ }^{79}$. This route would be quite similar to the Ottoman military road. However, recent discoveries of road surfaces allow one to determine that it ran via Köprühisar and Yarhisar (a more probable candidate for Agrillo) towards Ermeni Pazarı ${ }^{80}$. In that case, the Ottomans would have modified an earlier route, a scheme that is seen quite often in the development of the Ottoman road system.

Documents from the $17^{\text {th }}$ century, after the foundation of Vezirhan as a new road station in 1659/60, show yet another route from İznik to Eskişehir. It left the old Sangarios-Karasu road south of Bilecik and led to Eskişehir via Söğüt, the old cradle of the Ottomans ${ }^{81}$. It has been assumed that the armies of the First Crusade marched along this route from Nikaia to the battle field near Dorylaion ${ }^{82}$, but this assumption, which has not been resumed by later historians of the Crusades, cannot as yet be proved. It is therefore not at all sure that this variant was already known to the Byzantines, and so this may be another example of a new Ottoman road.

Like the Romans and the Byzantines, the Ottomans used several routes between Eskişehir (or İnönü) and Konya/Ikonion. The most important military and caravan road went south from Eskişehir through Seyyidgazi/Nakoleia, Bardakçı/Santabaris and Hanköy (Hüsrevpaşa Hanı founded in 1629, possibly the Byzantine Hebraikē) ${ }^{83}$ to Bayat (near Byzantine Kedrea, described as thriving, fortified market place by al-Idrīisi ${ }^{84}$, and via Bolvadin/Polybotos to Akşehir/Philomēlion $^{85}$. This is more or less the "intermediate road" first attested under the Comnenian emperor Alexios I.

To sum up: The foundations of the road network in Anatolia were laid by the Romans. It was so dense that the emergence of new political, economic and military centres usually did not require

\footnotetext{
77 Taeschner 1924-1926, 118-120 with tab. 5; Lefort 2003, 102-104, Pl. VI-VIII; Luther 1989, 109 (İznikYenişehir), 109-110 (Yenişehir-Pazaryeri), 88 (Pazaryeri-İnönü), 56 (İnönü-Eskişehir), 76 (Kütahyaİnönü).

78 Tabula Peutingeriana IX 2-3: Nicea XXIIII Agrillo XXXV Dorileo.

${ }^{79}$ Şahin 1981, 20.

${ }^{80}$ Kaplanoğlu 2000, 27-28; Belke 2017, 61-65; Belke 2020, 273.

${ }^{81}$ Taeschner 1924-1926, 122-124 with tab. 6; Luther 1989, 61-62 (İznik-Osmaneli-Vezirhan-Bilecik), 25 (Bilecik-Söğüt-Eskişehir).

${ }^{82}$ Runciman 1951, 186-187, n. 1.

${ }^{83}$ Eyice 1969.

${ }^{84}$ In Jaubert 1840, 304-306.

${ }^{85}$ Taeschner 1924-1926, 124-126 with tab. 7 and 8; Luther 198942 (Eskişehir-Seyyidgazi), 94-95 (Seyyidgazi-Hanköy), 51 (Hanköy-Bayat), 20 (Bayat-Bolvadin), 32-33 (Çay-Akşehir and Çay-Bolvadin).
} 
new roads to be built, but shifted traffic to other roads that already existed. So, the Byzantines, as later the Ottomans, inherited many roads from their predecessors. These were of course determined by the terrain and by the important centres. Some differences between the Byzantines and the Ottomans regarding new roads may reflect the number and quality of extant sources rather than real differences. The creation of new towns, such as Yenişehir, and the building of caravanserais and other pious foundations (e.g. Vezirhan or Hüsrevpaşa Hanı) by high-ranking officials of the Ottoman state, convey the impression that there were more changes of traditional routes during the Ottoman period than are known for the Byzantine period. The majority of the main lines of communication, however, survived from the Roman into the Ottoman period.

\section{Bibliography}

\section{Primary sources}

Ammianus Marcellinus

Ammianus Marcellinus, Römische Geschichte. Lateinisch und Deutsch und mit einem Kommentar versehen von W. Seyfarth, I-II. Darmstadt ${ }^{5} 1983$; III-IV. Darmstadt ${ }^{3} 1986$.

Anna

Annae Comnenae Alexias, ed. D. R. Reinsch - A. Kambylis, I-II (Corpus Fontium Historiae Byzantinae, 40, 1-2), Berlin 2001.

Geōrgios Pachymerēs

Georges Pachymérès, Relations historiques. Édition, introduction et notes par A. Failler, traduction française par V. Laurent (I-II), A. Failler (II-IV), index par A. Failler (V) (Corpus Fontium Historiae Byzantinae 24, 1-5), Paris 1984-2000.

Gesta Francorum Anonymi Gesta Francorum et aliorum Hierosolymitanorum, ed. H. Hagenmeyer, Heidelberg 1891.

Gregorii Nysseni Epistulae Gregorii Nysseni opera 8, Pars 2, Epistulae, ed. G. Pasquali, LeidenBoston-Köln ${ }^{2} 1998$.

Historia de Expeditione Friderici

Historia de Expeditione Friderici Imperatoris, ed. A. Chroust, Quellen zur Geschichte des Kreuzzuges Kaiser Friedrichs I (Monumenta Germaniae Historica, Scriptores rerum Germanicarum, Nova Series V), Berlin 1928.

Ibn Ḥauqal

Ibn Hauqal, Configuration de la terre (Kitab surat al-ard). Introduction et traduction, avec index, par J. H. Kramers et G. Wiet, I-II, Beyrouth-Paris 1964.

Ibn Hurdādbih

Kitâb al-Masâlik wa'l-Mamâlik (Liber viarum et regnorum), auctore Abu'l-Kâsim Obaidallah ibn Abdallah ibn Khordâdhbeh, ed. cum versione Gallica, M. J. de Goeje (Bibliotheca Geographorum Arabicorum 6), Lugduni Batavorum ${ }^{2} 1967$.

Iōannes Kinnamos

Ioannis Cinnami Epitome rerum ab Ioanne et Manuele Comnenis gestarum, ed. A. Meineke, Bonn 1836.

Iōannēs Skylitzēs

Ioannis Scylitzae Synopsis Historiarum, ed. I. Thurn (Corpus Fontium Historiae Byzantinae 5), Berlin 1973. 
Kōnstantinos Porphyrogennētos, Three Treasises

Kōnstantinos Porphyrogennētos, Vita Basilii

Julien, Lettres

Libanios, Autobiography

Michaēl Attaleiatēs

Nikēphoros Bryennios

Nikēphoros Chōniatēs

Odo of Deuil

Palladios, Dialogue

Prokopios, De aed.

Tabula Peutingeriana

Theophanēs

\section{Secondary Sources}

Adak 2019

Avramea 2002
Constantine Porphyrogenitus, Three Treatises on Imperial Military Expeditions. Introduction, edition, translation and commentary by J. F. Haldon (Corpus Fontium Historiae Byzantinae 28), Wien 1990.

Constantine VII Porphyrogenitus (attr.), Vita Basilii, edited by I. Ševčenko, Chronographiae quae Theophanis Continuati nomine fertur liber quo vita Basilii imperatoris amplectitur (Corpus Fontium Historiae Byzantinae 42), Berlin 2011.

L'empereur Julien, Oeuvres complètes, vol. I, 2, Lettres et fragments, ed. et trad. J. Bidez, Paris 1960.

Libanios, Autobiography (Or. 1), ed. J. Martin - P. Petit, Libanios, Discours, I, Paris 1979.

Michael Attaleiates, Historia, edited by I. Pérez Martín - M. Ataliates, Historia, Madrid 2002.

Nicephori Bryennii Historiae, edited by P. Gautier, Nicéphore Bryennios, Histoire (Corpus Fontium Historiae Byzantinae 9), Brussels 1975.

Nicetae Choniatae Historia, ed. J.-L. van Dieten, I, praefationem et textum Graecum continens (Corpus Fontium Historiae Byzantinae 11), Berlin-New York 1975.

Odo of Deuil, De profectione Ludovici VII in orientem, ed. V. G. Berry, New York 1948.

Palladios, Dialogue sur la vie de Jean Chrysostome, ed. A.-M. Malingrey - P. Leclerc, I-II, Paris 1988.

Procopii Caesariensis De aedificiis libri VI (= Opera omnia IV), ed. J. Haury - G. Wirth, Leipzig 1964.

E. Weber, Tabula Peutingeriana. Codex Vindobonensis 324. Vollständige Faksimile-Ausgabe im Originalformat. Kommentar, Graz 1976.

Theophanis Chronographia, ed. C. de Boor, I, textum Graecum continens, Leipzig 1883.

M. Adak, Küçük Asya'da Roma İmparatorluğu Dönemi'nde Ulaşım, İletişim ve Taşımacilık / Travel, Communication and Transportation in Asia Minor During the Roman Imperial Period, in: O. Tekin (ed.), Hellenistik ve Roma Dönemlerinde Anadolu. Krallar, İmparatorlar, Kent Devletleri / Hellenistic and Roman Anatolia. Kings, Emperors, City States, İstanbul 2019, 432-448.

A. Avramea, Land and Sea Communications, Fourth-Fifteenth Century, in: A. E. Laiou (ed.), The Economic History of Byzantium, I, Washington D.C., 2002, 57-90. 
Belke 1984

Belke 2000

Belke 2010

Belke 2011

Belke 2017

Belke 2020

Belke - Mersich 1990

Brand 1991

Bryer 2002

Bulliet 1975

Chevallier 1998

Dagron - Mihăescu 1986

Dimitroukas 1997

Dölger - Müller 2003

Eyice 1969

French 1974

French 1980
K. Belke, mit Beiträgen von M. Restle, Galatien und Lykaonien (TIB 4), Wien 1984.

K. Belke, Prokops De aedificiis, Buch V, zu Kleinasien, Antiquité Tardive 8, 2000, 115-125.

K. Belke, Verkehrsmittel und Reise- bzw. Transportgeschwindigkeiten zu Lande im Byzantinischen Reich, in: E. Kislinger - J. Koder A. Külzer (eds.), Handelsgüter und Verkehrswege. Aspekte der Warenversorgung im östlichen Mittelmeerraum (4. bis 15. Jahrhundert). Akten des Internationalen Symposions Wien, 19.-22. Oktober 2005 (Veröffentlichungen zur Byzanzforschung 18 = ÖAW, phil.hist. Kl., Denkschriften 388), Wien 2010, 45-58.

K. Belke, Byzanz und die Anfänge des rumseldschukischen Staates. Bemerkungen zur Chronologie von Anna Komnēnēs „Alexias“ in den Jahren 1084-1093, Jahrbuch der Österreichischen Byzantinistik 61, 2011, 65-79.

K. Belke, Bithynien und Hellespont in der Tabula Peutingeriana, in: A. Külzer - M. St. Popović (eds.), Space, Landscapes and Settlements in Byzantium: Studies in Historical Geography of the Eastern Mediterranean, Novi Sad-Vienna 2017, 51-73.

K. Belke, Bithynien und Hellespont (TIB 13), Wien 2020.

K. Belke - N. Mersich, Phrygien und Pisidien (TIB 7), Wien 1990.

C. M. Brand, Tzachas, The Oxford Dictionary of Byzantium III, $1991,2134$.

A. Bryer, The Means of Agricultural Production: Muscles and Tools, in: A. E. Laiou (ed.), The Economic History of Byzantium I, Washington, D.C. 2002, 101-113.

R. W. Bulliet, The Camel and the Wheel, Cambridge, Mass. 1975.

R. Chevallier, Les voies Romaines, Paris ${ }^{2} 1998$.

G. Dragon - H. Mihăescu, Le traité sur la guérilla (De velitatione) de l'empereur Nicéphore Phokas (963-969), Paris 1986.

I. Ch. Dimitroukas, Reisen und Verkehr im Byzantinischen Reich vom Anfang des 6. Jhr bis zur Mitte des 11 Jhr., I-II, Athen 1997.

F. Dölger, Regesten der Kaiserurkunden des Öströmischen Reiches von 565-1453, I, 2, Regesten von 867-1025, 2. Auflage von A. Müller, München 2003.

S. Eyice, Hanköyü'nde Husrev Paşa Camii, Tarih Dergisi 23, 1969, 179-204.

D French, A Study of Roman Roads in Anatolia: Principles and Methods, Anatolian Studies 24, 1974, 143-49.

D. French, The Roman Road-system of Asia Minor, in: H. Temporini (ed.), Aufstieg und Niedergang der Römischen Welt 7/2, Berlin 1980, 698-729. 
French 1981

French 1993

French 2012

French 2013

Hagenmeyer 1898

Haldon 2006a

Haldon 2006b

Haldon 2012

Hewsen 1992

Hild 1977

Hild - Restle 1981

Honigmann 1936

Huxley 1975

Jaubert 1840

Kaplan 2000
D. French, Roman Roads and Milestones of Asia Minor, Fasc. 1: The Pilgrim's Road (British Archaeological Reports, International Series, 105), Oxford 1981.

D. French, A Road Problem: Roman or Byzantine?, Istanbuler Mitteilungen 43, 1993, 445-454.

D. French, Roman Roads and Milestones of Asia Minor, III. Milestones, Fasc. 3.3, Cappadocia (British Institute at Ankara, Electronic Monograph 3), Ankara 2012.

D. French, Roman Roads and Milestones of Asia Minor, III. Milestones, Fasc. 3.4, Pontus et Bithynia (with Northern Galatia) (British Institute at Ankara, Electronic Monograph 4), Ankara 2013.

H. Hagenmeyer, Chronologie de la première Croisade (1094-1100), Revue de l'Orient Latin 6, 1898, 214-93, 490-549.

J. Haldon, Roads and communications in the Byzantine Empire: wagons, horses, and supplies, in: J. H. Prior (ed.), Logistics and Warfare in the Age of the Crusades, Aldershot 2006, 131-158.

J. Haldon, Introduction. Why model logistical systems?, in: J. Haldon (ed.), General Issues in the Study of Medieval Logistics, LeidenBoston 2006, 1-35.

J. Haldon, Commerce and Exchange in the Seventh and Eighth Centuries. Regional Trade and the Movement of Goods, in: C. Morrisson (ed.), Trade and Markets in Byzantium, Washington 2012, 99-122.

R. H. Hewsen, The Geography of Ananias of Šrak (AŠXARHAC' OYC'). The Long and the Short Recensions. Introduction, Translation and Commentary (Beihefte zum Tübinger Atlas des Vorderen Orients, Reihe B [Geisteswissenschaften] 77), Wiesbaden 1992.

F. Hild, Das byzantinische Straßensystem in Kappadokien (Veröffentlichungen der Kommission für die Tabula Imperii Byzantini 2), Wien 1977.

F. Hild - M. Restle Kappadokien (Kappadokia, Charsianon, Sebasteia und Lykandos) (TIB 2), Wien 1981.

E. Honigmann, Un itinéraire arabe à travers le Pont, Annuaire de l'Institut de Philologie et d'Histoire Orientales et Slaves 4 (= Mélanges Franz Cumont), 1936, 261-71.

G. Huxley, A List of ä $\pi \lambda \eta \kappa \tau \alpha$, Greek, Roman, and Byzantine Studies $16,1975,87-93$.

A. Jaubert, Géographie d'Édrisi traduite et accompagnée de notes, III (Recueil de Voyages et Mémoires 5, 6), Paris 1836-1840.

M. Kaplan, Quelques remarques sur les routes à grande circulation dans l'empire byzantine du VI ${ }^{e}$ au XI ${ }^{e}$ siècle, in: A. Dierkens - J.-M. Sansterre, avec la collaboration de J.-L. Kupper (eds.), Voyages et voyageurs à Byzance et en Occident du VI ${ }^{\mathrm{e}}$ au XI siècle, Actes du 
Kaplanoğlu 2000

Kaya 2019

Kolb 2000

Laiou - Morrisson 2007

Lefort 1995

Lefort 2003

Leiser 1998

Lilie 1976

Lopez 1945

Loungēs 1994-1995

Luther 1989

Mélikoff 1965

Mitchell 1976

Pekáry 1968 colloque international organisé par la Section d'Histoire de l'Université Libre de Bruxelles en collaboration avec le Département des Sciences Historiques de l'Université de Liège (5-7 mai 1994) (Bibliothèque de la Faculté de Philosophie et Lettres de l'Université de Liège 278), Genève 2000, 83-100.

R. Kaplanoğlu, Osmanlı Devleti'nin Kuruluşu (Avrasya Etnografya Vakfi Yayınları 7), Bursa 2000.

T. Kaya, Understanding the Use of Byzantine Routes in Central Anatolia (ca. $7^{\text {th }}-9^{\text {th }}$ Centuries), Studia Ceranea 9, 2019, 259-278.

A. Kolb, Transport und Nachrichtentransfer im Römischen Reich, Berlin 2000.

A. E. Laiou - C. Morrisson, The Byzantine Economy, Cambridge etc. 2007.

J. Lefort, Les communications entre Constantinople et la Bithynie, in: C. Mango - G. Dagron (eds.), Constantinople and its Hinterland. Papers from the Twenty-seventh Spring Symposium of Byzantine Studies, Oxford, April 1993 (Society for the Promotion of Byzantine Studies 3), Aldershot 1995, 207-218.

J. Lefort, Les miniatures de Matrakçı, in: B. Geyer - J. Lefort (eds.), La Bithynie au Meyen Âge, Paris 2003, 99-112.

G. Leiser, Sulaymān b. Kutulmish, Encyclopédie de l'Islam, nouvelle édition 9, 1998, 860.

R.-J. Lilie, Die byzantinische Reaktion auf die Ausbreitung der Araber (Miscellanea Byzantina Monacensia 22), München 1976.

R. S. Lopez, Silk Industry in the Byzantine Empire, Speculum 20, 1945, 1-42 (repr. In: R. S. Lopez, Byzantium and the world around it: Economic and Institutional Relations, London 1978 [Variorum Reprints, Collected Studies 85], Variorum Reprints, No. III).

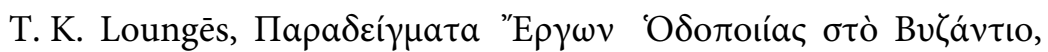
Diptycha Hetaireias Byzantinōn kai Metabyzantinōn Meletōn 6 (= Mnēmē Bruno Lavagnini), 1994-1995, 37-48.

U. M. Luther, Historical Route Network of Anatolia (Istanbul-Izmir-Konya), 1550's to 1850's: A Methodological Study, Ankara 1998.

I. Mélikoff, Danishmendids, Encyclopédie de l'Islam, nouvelle édition 2, 1965, 112-114.

S. Mitchell, Requisitioned Transport in the Roman Empire: A New Inscription from Pisidia, Journal of Roman Studies 66, 1976, 106-131.

Th. Pekáry, Untersuchungen zu den römischen Reichsstraßen (Antiquitas, Reihe 1, Abhandlungen zur Alten Geschichte 17), Bonn 1968. 
Rathmann 2003

Redford in print

Runciman 1951

Şahin 1981

Schneider 1982

Stauridou-Zaphraka 1982

Taeschner 1924-1926

Turchetto in print

Vryonis 1971

Yavuzcan 2011
M. Rathmann, Untersuchungen zu den Reichsstraßen in den westlichen Provinzen des Imperium Romanum (Beihefte Bonner Jahrbücher 55), Mainz 2003.

S. Redford, Towards a Social History of Seljuk Caravanserais and Routes (Pathways of Communication. Roads and routes in Anatolia from prehistory to Seljuk times, International Conference 20-22 March 2014, Ankara), in print.

S. Runciman, A History of the Crusades I. The first crusade and the foundation of the Kingdom of Jerusalem, Cambridge 1951.

S. Şahin, Katalog der antiken Inschriften des Museums von Iznik (Nikaia). İznik Müsesi antik yazıtlar kataloğu II, 1 (IK 10,1), Bonn 1981.

H.-Chr. Schneider, Altstraßenforschung (Erträge der Forschung 170), Darmstadt 1982.

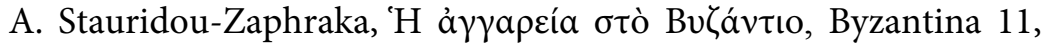
1982, 21-54.

F. Taeschner, Das anatolische Wegenetz nach osmanischen Quellen, I-II, Leipzig 1924-1926.

J. Turchetto, Old, new or ever-lasting roads? 'Route inertia', movement corridors and Seljuk caravanserais in medieval Anatolia (Frontier, Periphery or Centre? Society and Material Culture in Medieval Anatolia, Conference Edinburgh 19 June 2015), in print.

S. Vryonis, Jr., The Decline of Medieval Hellenism in Asia Minor and the Process of Islamization from the Eleventh through the Fifteenth Century, Berkeley-Los Angeles-London 1971.

G. Yavuzcan, Türkiye Selçukluları'nda Ulaşım ve İktidar, in: A. Şişman et al. (eds.), CIEPO, Uluslararası Osmanlı Öncesi ve Osmanlı Tarihi Araştırmaları, 6. Ara Dönem Sempozyu Bildirileri,14-16 Nisan 2011 Uşak, İzmir 2011, 49-60.

\section{Merkezi/Orta Küçük Asya'nın Kuzeybatı ve Komşu Bölgelerindeki Yollar ve Güzergâhlar: Roma'dan Bizans'a, Osmanlı Dönemi'nde 17. Yüzyıla Kadarki Kaderlerine Dair Bazı Yorumlar Öz}

Çalışma, kuzeybatı Küçük Asya'daki (ve merkezi/orta bölümlerindeki) Roma'dan Bizans Dönemi'ne kadar olan yolların gelişimini inceleyerek, Türk döneminde 17. yüzyıla kadar bazı değişikliklere işaret eder. Uzun mesafeli trafiğin ana güzergâhlarına ilişkin dikkate değer bir süreklilik bulunmakta, ancak bu güzergâhlar, farklı askeri ve ekonomik odaklara ve ihtiyaçlara karşılık gelecek şekilde ayrıntılı olarak değişebilmekteydi. Yolların tasarım ve yapım teknikleri değişmişti; devlet ekonomik kaynaklara bağlı olarak vagonlar ve at arabalarından yük hayvanlarına kadar olan değişime harcama yapabiliyordu. Antikçağ’ın sonunda Roma İmparatorluk Dönemi'nin geniş, taş döşemeli uzun-mesafe yollarının ihmal edilmesi Küçük Asya'daki taşıt trafiğinin kademeli olarak azalmasıyla bağlantılıdır. İ. S. 6. yüzyıla kadar seyahat ve taşıma, basit kağnı arabaları üzerindeki kısa mesafe taşımacılığı hariç, binek ve yük hayvanlarına dayanmaktadır. Yollar bu ulaşım araçlarına uyarlanmış, daha dar bir hale gelmiş ve sarp geçitlerde basamaklandırılmıştır. 
7. yüzyıldan itibaren doğu eyaletlerinin kaybedilmesinin ardından ve Anadolu'nun neredeyse yıllık gerçekleşen Arap istilaları sırasında, Bizanslılar Roma Dönemi'nin ve Geç Antik Çağ’’n ana yollarından kısmen farklı olan, ancak çoğunlukla Roma seleflerinden miras kalan yolları seçti. Küçük Asya boyunca ana yollar genellikle kabul edilebilir bir düzen içinde tutuldu, ancak çok az yeni yol inşa edildi.

Selçuklu fethinden sonra yollar tekrardan emniyetsiz bir duruma geldi. Ana iletişim hatları en azından Bizans kontrolü altındaki bölgelerde değişmedi. Osmanlılar, Bizanslıların askeri seferler ve ticaret için kullandıkları yolların çoğunu devraldı. Yine de en azından sınırlı sayıya sahip tamamen yeni yol inşa etmeye hazır oldukları anlaşılmaktadır. Bina teknikleri aşağı yukarı Bizans seleflerinin örneklerini izlemiştir.

Anahtar Sözcükler: Küçük Asya, Roma, Bizans ve Osmanlı yolları, yol yapım tekniği, yol yüzeyleri, trafik araçları, Roma'dan Osmanlı'ya kadar olan iletişim yollarının geliştirilmesi.

\section{Roads and Routes in Northwestern and Adjoining Parts of Central Asia Minor: From the Romans to Byzantium, with Some Remarks on their Fate during the Ottoman Period up to the $17^{\text {th }}$ Century}

\section{Abstract}

The paper examines the development of roads in northwestern (and parts of Central) Asia Minor from the Roman to the Byzantine period, pointing also to some changes in the Turkish period until about the $17^{\text {th }}$ century. There was a remarkable continuity regarding the main routes of longdistance traffic, but these routes could change in detail, corresponding to different military and economic focuses and needs. Design and building techniques of the roads changed, depending on the economic resources the state was able to spend and above all on the change from wagons and carts to pack animals. Neglect of the wide, paved long-distance roads of the Roman imperial period at the end of antiquity was linked to the gradual decrease of vehicular traffic in Asia Minor. By the sixth century AD, travel and transport relied on mounts and pack animals, except for some short-distance transportation on simple oxcarts. Roads were adapted to these means of transport and became narrower and stepped at steep passages.

From the seventh century onwards, following the loss of the eastern provinces and during the nearly annual Arab invasions of Anatolia, the Byzantines chose routes that were partly different from the main routes of the Roman period and Late Antiquity, but which mostly were also inherited from their Roman predecessors. The main routes through Asia Minor were generally maintained in an acceptable order, but very few really new roads were built.

After the Seljuk conquests roads became insecure again. The main lines of communication did not change, at least not in regions under Byzantine control. The Ottomans took over most of the roads used by the Byzantines for their military campaigns and for trade. It seems, however, that they were readier to build at least a limited number of entirely new roads. Their building techniques more or less followed the examples of their Byzantine predecessors.

Keywords: Asia Minor, Roman, Byzantine and Ottoman roads, road building technique, road surfaces, means of traffic, development of communication routes from Roman to Ottoman. 


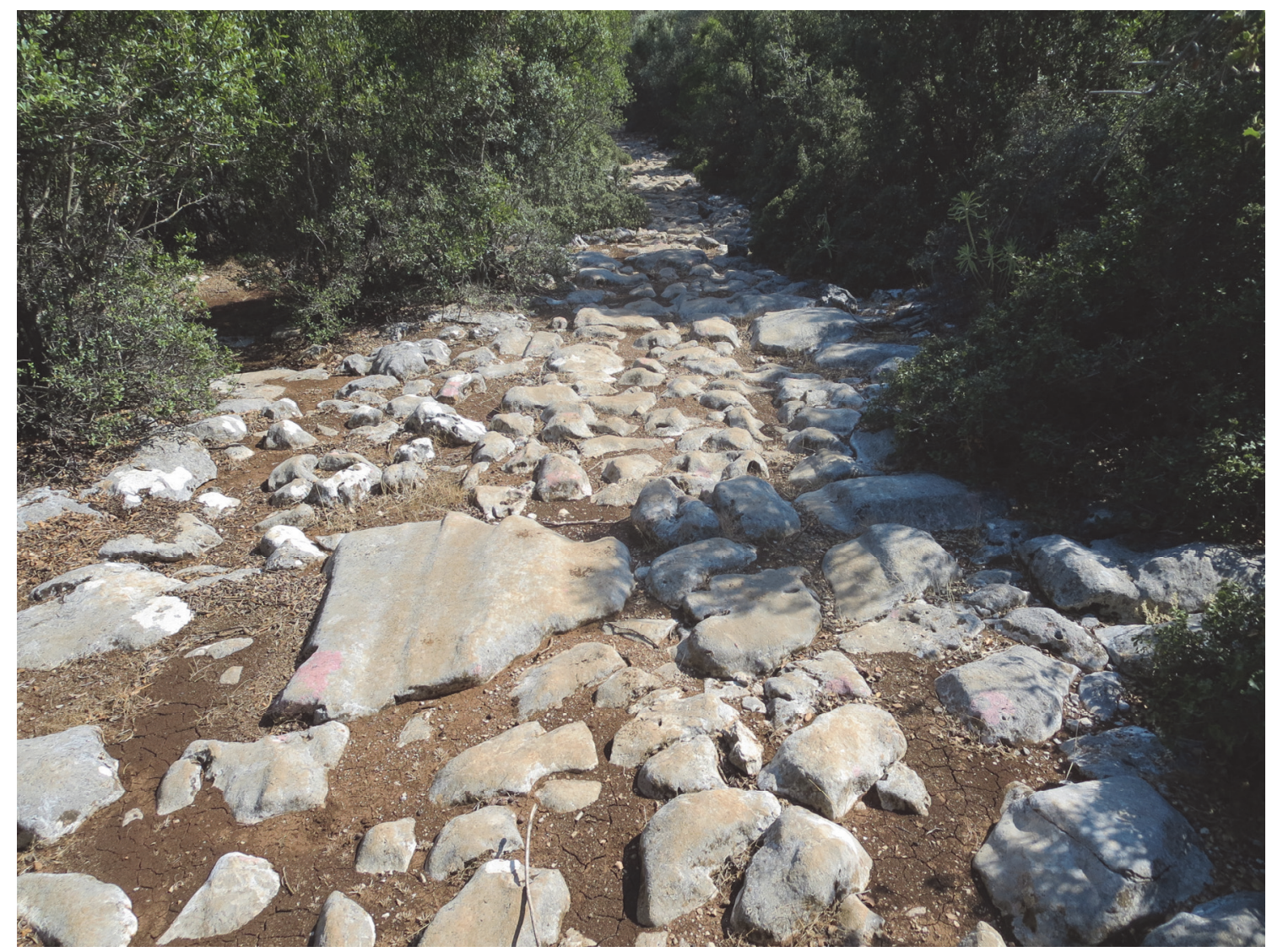

Fig. 1) Roman Via Sebaste in the Döșeme Boğazı (Pamphylia) with ruts

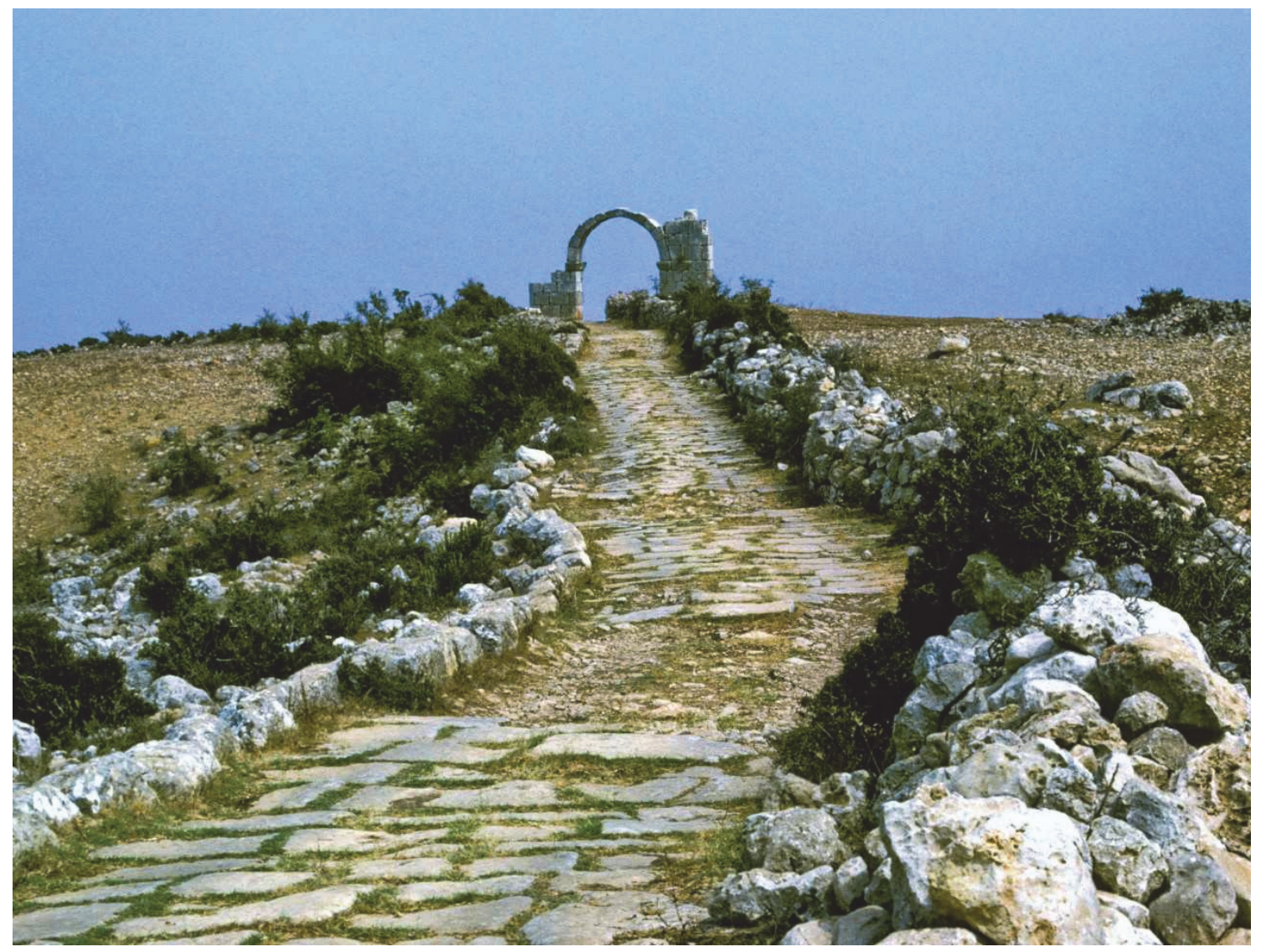

Fig. 2) Early Byzantine road near Sağlıklı (Cilicia) 


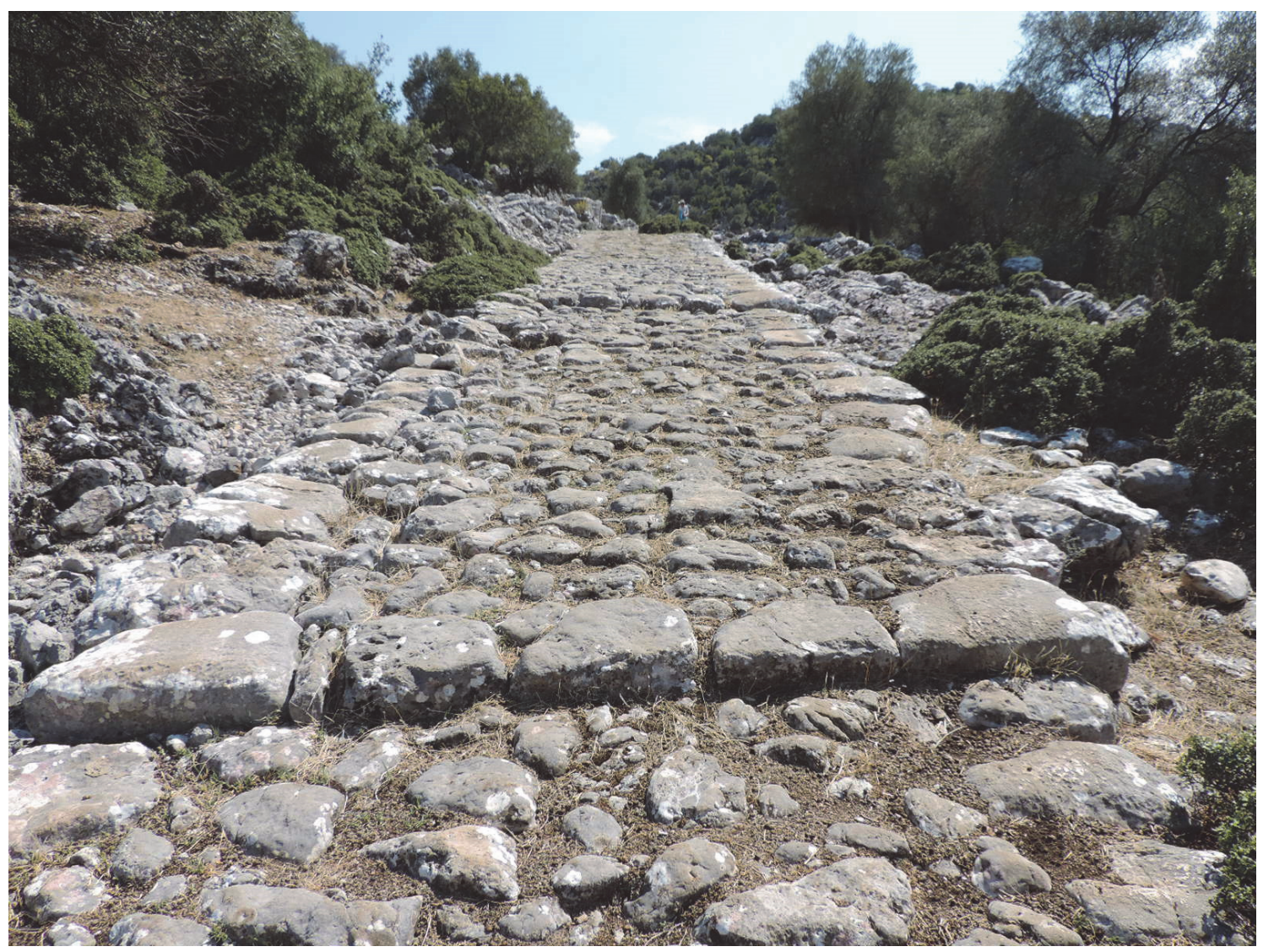

Fig. 3) Byzantine or (rather) Ottoman road in the Döşeme Boğazı (Pamphylia) with steps

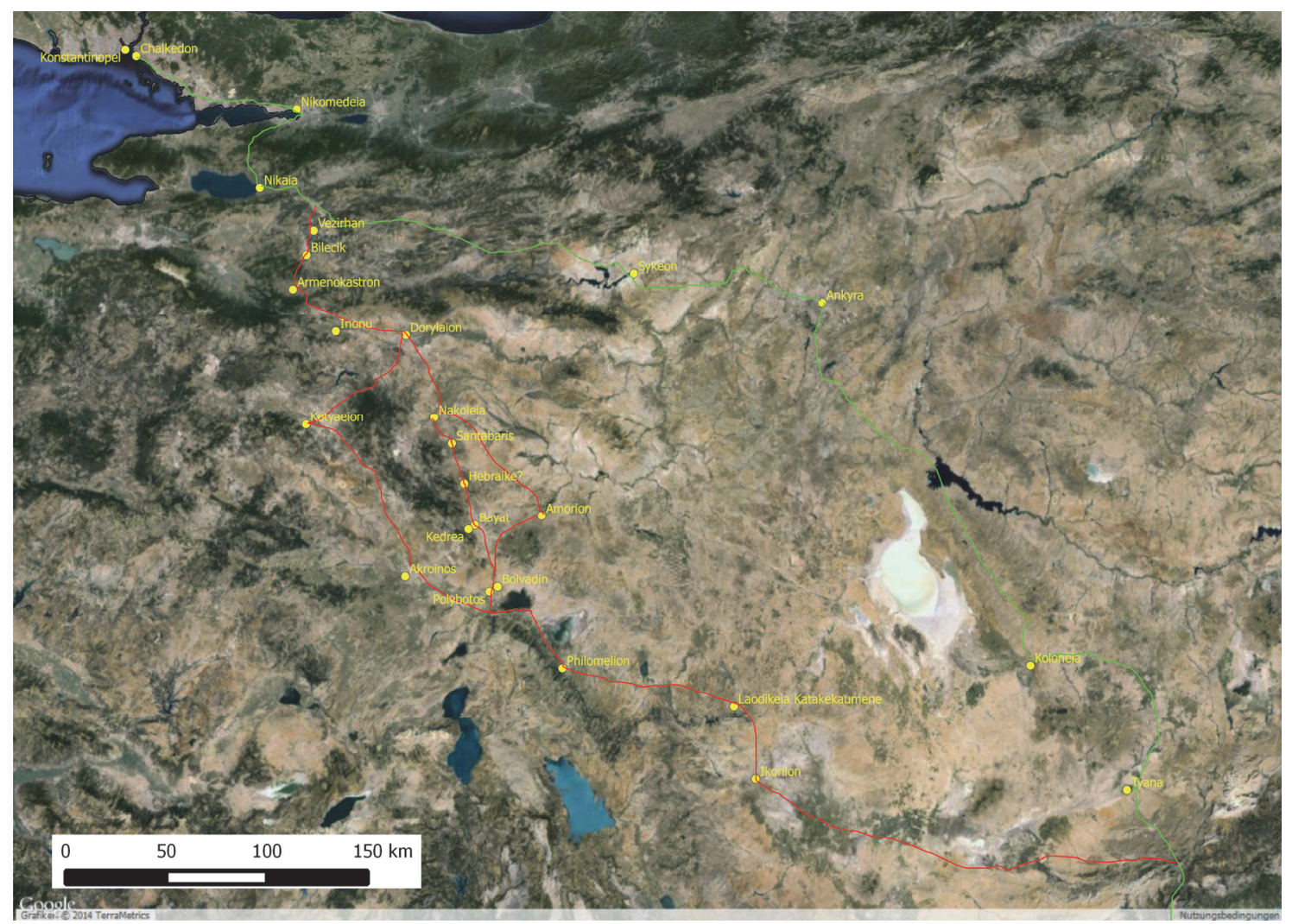

Fig. 4) Map showing the "Pilgrim's Road" and its Middle Byzantine variants 
Kleinasien in byzantinischer Zeit

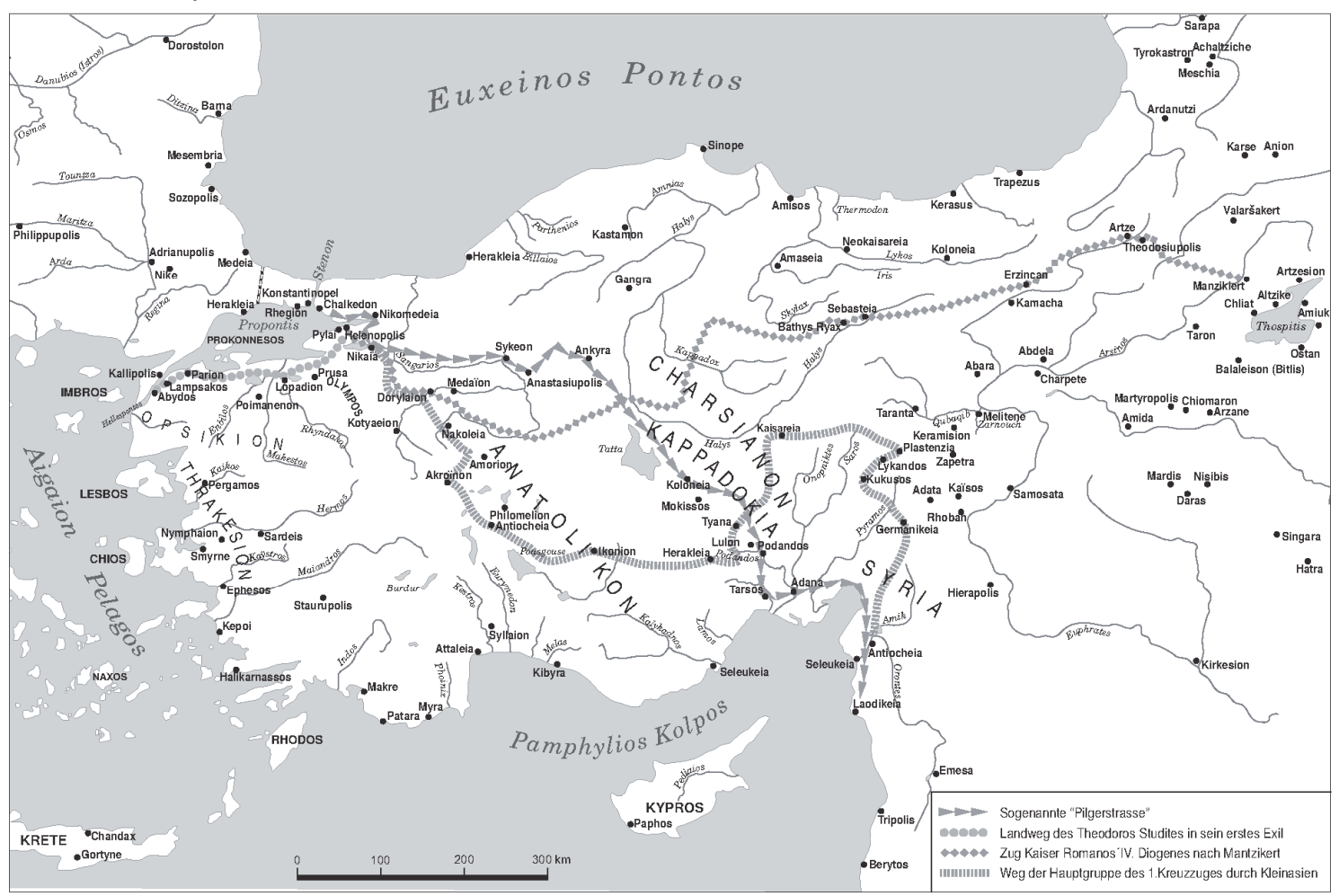

Fig. 5) Map showing (among other routes) the march of Romanos IV to Mantzikert (from Belke 2010)

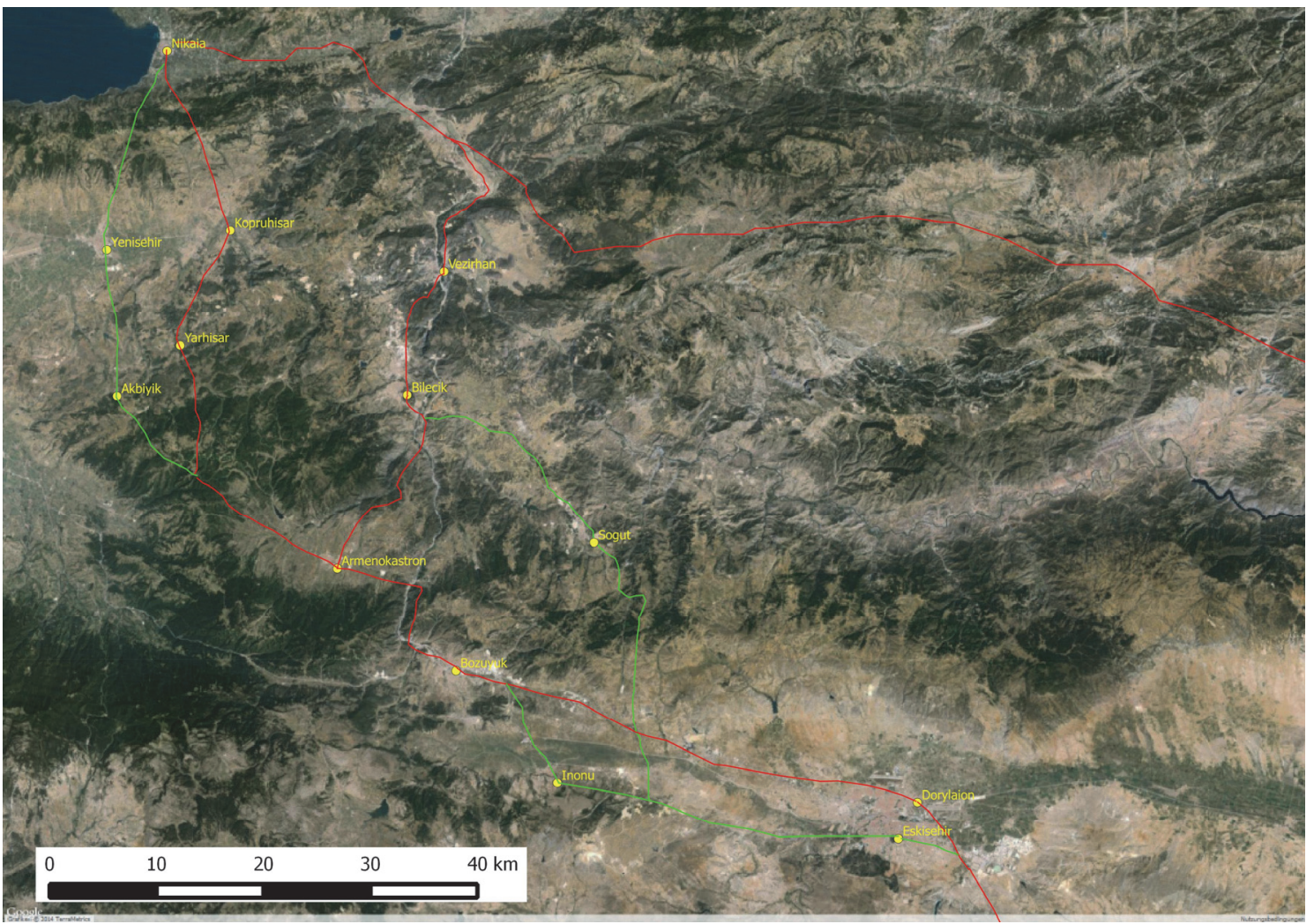

Fig. 6) Map showing the Byzantine and Ottoman (if presumably different) roads between Nikaia (İzik) and Dorylaion (or Eskişehir respectively) 